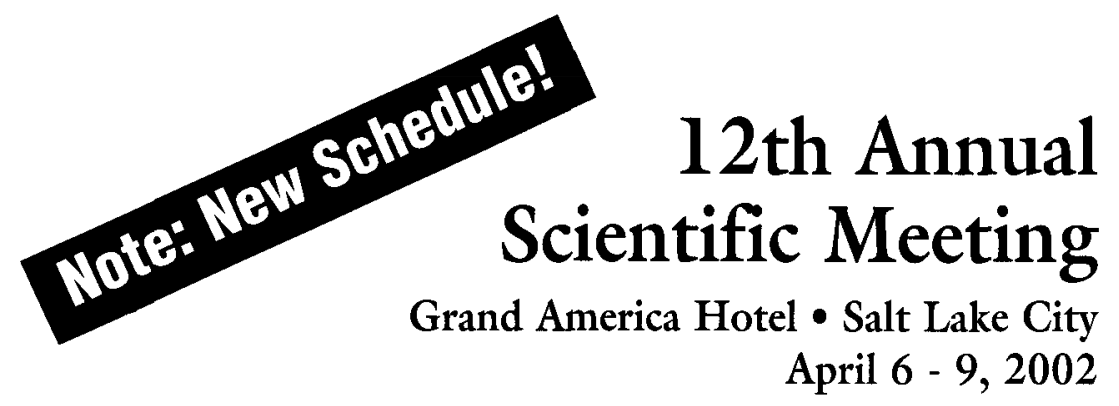

\section{Opening Plenary Session}

"The Future Ain't What it Used to Be Coordinating a Bioterrorism Response"

- Exotic Weaponization Schemes

- Logistics of Operationalizing a Bioterrorism Plan

- Governmental Response to Bioterrorism

Opening Reception

7:00 pm - 8:15 pm

\section{Workshops} Saturday, April 6, 2002

- Evidence Based Infection Control, M. Loeb and C. Walker-Dilks

- Media Relations: Communicating in Crisis, J. Rodgers

- Computer Database Support for Assessment and Control of Antibiotic Resistance, M. Samore

- JCAHO: New Safety Rules and Their Implementation, T. Lundstrom

- Bioterrorism-The Interface Between Public Health and Infection Control: Lessons Learned, M. Leyton

Plenary Sessions

\section{PRION DISEASE: LESSONS FROM EUROPE}

1. Update on the Biology and Epidemiology of Prion Diseases, R. Will

2. Sterilization-Disinfection, European Approach, D. Pittet

3. Sterilization/Disinfection for Prion Disease, US Perspective, W. Rutula

4. Safety of Blood Supply, H. Budka

IMPORTATION OF EXOTIC PATHOGENS: ARE YOU PREPARED?

1. Viral Hemorrhagic Fever, M. Loeb

2. Rift Valley Fever, Z. Memish

3. Glanders, A. Srinivasan

PREVENTION OF ANTIBIOTIC RESISTANCE: NEW APPROACHES

1. Antibiotic Cycling: "It's Hard To Hit A Moving Target", N. Fishman

2. Decolonization Protocols, L. Herwaldt

3. Alternatives to Traditional Antibiotics: Probiotics and Antimicrobial Peptides, M. Yeaman

PATIENT SAFETY-NEW HORIZONS IN INFECTION CONTROL

1. The Science of Safety, P. Pronovost

2. Patient Safety: Translating Concern into Change, B. James

3. The Role of the Hospital Epidemiologist in Patient Safety and Improving Patient Care, J. Gerberding

\section{Symposia}

\section{SURGERY AND PREVENTING ADVERSE EVENTS}

1. The Changing Face of Surgical Site Infections: More Common, Different Microbial Etiology?, R. Sherertz

2. Metabolic Approaches to Prevention: Impact of Temperature, Oxygen Saturation, and Glucose Control, J. Lee

3. Systemic vs. Local Antimicrobials to Prevent Infections of Surgically Impianted Prostheses, R. Darouiche

4. Decolonizing Patients to Prevent Infections: The Mupirocin Story, T. Perl

UPDATE ON PEDIATRIC INFECTION CONTROL:

NEW APPROACHES TO OLD PROBLEMS

1. PICU-Associated Infections: Getting to the Heart of the Matter, $N$. Singh

2. Computer-Based Decision Support Succeed Where Physicians Have Failed?, W. C. Huskins

3. Evidence-based Consensus Guidelines for Infection Control Practices among Patients with Cystic Fibrosis 2002: What?, Why? and How?, L. Saiman

\section{Symposia}

PERSISTENT AND PERPLEXING PROBLEMS IN INFECTION CONTROL: WHAT IS YOUR OPINION?

1. Is routine air sampling for aspergillus worthwhile for improving patient safety in bone marrow transplant units?, L. Dembry

2. Is the scientific basis for wearing surgical masks in the operating room beyond question?, $R$. Sherertz

3. An Ethical Dilemma: When should an outbreak investigation become the public's right to know? L. Herwaldt

4. Annual influenza vaccination of healthcare personnel should be mandatory as a patient safety intervention?, $T$. Lane

5. Should surgeon-specific feedback of surgical site infections (SSl's) be a routine infection control and quality practice?, C. Lerner

6. Should potable water in all healthcare institutions be periodically cultured for Legionella and should routine culture or urinary antigen assay for Legionella be periodically performed on patients with nosocomial pneumonia?, R. Besser

\section{PREVENTING ERRORS: NEW DIAGNOSTICS}

1. New Techniques in Bacteriology, Including Rapid Detection of MEC, T. Smith

2. New Test in the Diagnosis of Viruses Important in Infection Control, R. Thomson

3. A Cost-Effectiveness Analysis of these Tests for Infection Prevention, L. B. Reller

INFORMATICS: AN INFECTION PREVENTION/PATIENT SAFETY TOOL

1. Where we'll be in the year 2012: An Overview, R. Wurtz

2. Where are we now?, J. Overhage

3. How to make the most of the CIS data you have, S. Brossette

\section{Meet the Consultant Breakfasts}

- Hand Hygiene, J. Boyce and D. Pittet

- Legionella-What Type of Surveillance Should be Done?, R. Besser and L. Herwaldt

- HICPAC Guidelines: What's New, R. Weinstein and M. Pearson

- Advanced Issues in Health Care Workers Exposed to Bloodborne Diseases, K. Sepkowitz and D. Henderson

- Endoscopy, M. Favero and W. Rutala

- Working Patient Safety into Your Infection Control Program, G. Pugliese and T. Lundstrom

- Outbreak Investigation and Control, L. Dembry and W. Jarvis

- Infections in Immuno-compromised Hosts, K. Sepkowitz and G. Noskin

- Sterilization/Disinfection, M. Favero and W. Rutala

- Immunizations in Healthcare Workers, R. Wurtz and J. Siegel

- Controversies in Isolation, M. Rupp and T. Karchmer

- Bioterrorism-Lessons from the Front Line, M. Tapper and N. Singh

For additional information regarding the SHEA Annual Meeting, please contact: www.shea-online.org

SHEA Meetings Department

19 Mantua Road

Mt. Royal, NJ 08061

Telephone: (856) 423-7222, ext. 350

Fax: (856) 423-3420

Email: sheamtg@taliey.com 